that a very small pericardial effusion can be diagnosed radiologically and even by percussion will meet with some scepticism. The radiological appearance which he refers to as the pericardial hydropic triangle due to a small but pathological pericardial effusion most cardiologists would accept as a pericardial pad of fat of no clinical significance.

The best part of the book is his description of the veins of the heart based on results of injecting them with a tin-cadmium alloy, the preparation being freed from tissue by the activity of ants. His claim that a solid stethoscope is a better conductor of heart sounds than the usual type consisting of hollow tubes needs confirmation.

\section{PRACTICAL TEXTBOOK - OF LEPROSY}

By R. G. Cochrane, M.D., F.R.C.P., D.T.M. \& H. Geoffrey Cumberlege, Oxford University Press, r 947. Pp. 283. Price 42.

This book lives up to its title, for it is essentially practical throughout, and bears the stamp of wide experience. The author is convinced that the great majority of lepers are infected before the age of $\mathrm{I}_{5}$; that such infections occur mainly from household contact with a case of 'open' leprosy; and that the disease cannot be maintained in a community in the absence of child infection. The technique of. examining suspected cases is admirably described. The old method of preparing smears by puncturing the skin with a needle has been entirely superseded, and the improved procedure for demonstrating the bacillus is carefully detailed step by step, and illustrated by explanatory photographs. Clinical features of the disease and its treatment are dealt with in the same practical and thorough fashion, with many helpful ' tips' and much wise counsel. There is a full account of the methods of leprosy control as illustrated by the leprosy campaign in the Madras Presidency.

The author's brief account of leprosy in England cannot pass unchallenged. He attributes the disappearance of the disease mainly to "the strict laws of segregation.' Actually there was little real segregation, and the reading of the burial service over a living leper, as described, was never a general practice in this country. For example, the rules of the Sherburn leper hospital, the largest in England, expressly permitted inmates to receive their friends, and such visitors from a distance could remain for the right. Further, persistently troublesome lepers were expelled. Lepers, true or supposed, had a legal right to beg, and in some towns they could also take toll of food on sale in the market-place. They could refuse to enter a leper-house, and in 1344 it is recorded of St. Julian's that in general there were no more than three inmates, and sometimes only one, because of the difficulty of finding lepers willing to lead a restricted life.

An impressive figure, 283 , is quoted as the number of leper-houses in England. The status of many of these dlleged leper-houses is doubtful, and if it is assumed that at any period this number were in active operation, each maintaining its specified complement of lepers, we are far from the truth. Some, like St. John's, Aylesbury, were nothing more than almshouses. In others, lepers and paupers had an equal right to the accommodation. Thus, for example, Ripon leper-house was endowed for I 8 persons, leprous or indigent ; and St. Bartholomew's, Oxford, for two healthy inmates, and six leprous or infirm. There were no lepers in either of these 'leper-houses' when virited by the King's Commissioners in 1341. Foundations established exclusively for lepers were transferred to other purposes. St. James's, Canterbury, endowed for 25 women lepers, was empty of lepers in I34I. Sherburn, founded for 65 lepers, in 1434, could produce only 13 poor men, and no lepers. Romney leper-house in 1363 is 'derelict and totally desolate,' because ' for long times past' no lepers could be discovered; it was repaired and put to other uses.

In this connection the Black Death is mentioned and its date in England given as 1340 , instead of I 348-49.

These criticisms of what is only a short digression are not meant to detract from the merit of this authoritative textbook. It is Dr. Cochrane's hope that it will prove helpful to practitioners, to those in charge of institutions, as well as to the specialist. One does not require the special gifts of a prophet, or a prophet's son, to foretell the speedy fulfilment of his hope.

\section{PSYCHOPATHOLOGY-A SURVEY OF} MODERN APPROACHES

By J. ERnest Nicole, O.B.E., L.M.S.S.A., D.P.M., R.C.P. \& S. Baillière, Tindall and Cox. 4th Edition. 1946. Pp. viii and 268. Price I5s.

' The author hopes he has been successful in marshalling some sort of orderly disposition out of the chaos of modern theory.' This phrase from the editorial of the first edition summarizes the aims of this very readable book which to the student and general practitioner has done more to clarify a very clouded picture than any other. As an introduction to the subject for those specializing in Psychiatry it cannot be bettered especially in view of the up-todate bibliography with its well selected priorities for further reading.

The Fourth Edition appears with few alterations, the theories of the various schools are reviewed with clarity, woolly and unnecessary verbage has been ruthlessly discarded. The author makes a plea for a unified terminology and it is to be hoped that this helpful suggestion will be realized speedily and not be relegated, as it seems has the New Classification of Psychiatric Disorders, to the limbo of forgotten things.

The chapter on Eclectics and Characterologists is of great value, the author strcsses that there is in this country a growing class of psychotherapeutists whose outlook is largely Freudian without being ' all Freud and nothing but Freud.' Crichton- 